\title{
PEMAHAMAN MAHASISWA AKUNTANSI TENTANG ASET, KEWAJIBAN DAN EKUITAS
}

\author{
Moch. Shulthoni \\ Rachma Arifanti \\ Politeknik Kediri \\ Shulthon@yahoo.com
}

\begin{abstract}
This study aims to determine the factors that affect accounting student understanding of the meaning of assets, liabilities, and equity. Accounting understanding of the individual will deliver a discourse and important decisions related to the condition of a company's managerial. The sample in this study are students of accounting in accordance with the requirements of several universities in Kediri. Testing the hypothesis in this study using the test the coefficient of determination (R2), the model significance test ( $\mathrm{F}$ test) and individual parameter significance test (Test $\mathrm{T}$ ) which shows every independent variables affect the dependent variable. Results from this study indicate that the college and the learning method of accounting does not affect the student's understanding of the meaning of assets, liabilities and equity and interest accounting subjects and majors origin accounting schools affects students' understanding of the meaning of assets, liabilities and equity.
\end{abstract}

\section{Keywords: Asset, Liability, Equity, Teaching Method}

\begin{abstract}
Abstrak: Penelitian ini bertujuan untuk mengetahui faktor-faktor yang mempengaruhi pemahaman mahasiswa akuntansi terhadap makna aset, kewajiban, dan ekuitas. Pemahaman akuntansi yang dimiliki individu akan memberikan sebuah wacana dan keputusan penting yang berhubungan dengan kondisi manajerial sebuah perusahaan. Sampel dalam penelitian ini adalah mahasiswa akuntansi yang sesuai dengan syarat dari beberapa perguruan tinggi di Kota Kediri. Pengujian hipotesis dalam penelitian ini menggunakan uji koefisien determinasi $\left(\mathrm{R}^{2}\right)$, uji keberartian model (uji F) dan Uji signifikansi parameter individual (Uji T) yang menunjukkan setiap variabel independen berpengaruh terhadap variabel dependen. Hasil dari penelitian ini menunjukkan bahwa perguruan tinggi dan metode pembelajaran tidak mempengaruhi pemahaman mahasiswa akuntansi terhadap makna aset, kewajiban dan ekuitas dan minat mata kuliah akuntansi dan jurusan asal sekolah mempengaruhi pemahaman mahasiswa akuntansi terhadap makna aset, kewajiban dan ekuitas.
\end{abstract}

Kata Kunci: Aset, Kewajiban, Ekuitas, Metode Mengajar 
Pertumbuhan perekonomian di Indonesia setiap tahun mengalami peningkatan dan memacu perkembangan dunia usaha. Perkembangan dunia usaha yang pesat ditandai dengan semakin banyaknya pendirian perusahaan dan permintaan tenaga kerja yang mengalami peningkatan. Setiap perusahaan atau usaha yang sedang berkembang membutuhkan laporan keuangan yang baku sesuai dengan Standar Akuntansi Keuangan (SAK). Penyusunan laporan keuangan dilakukan oleh tenaga ahli di bidang akuntansi yang disebut akuntan.

Akuntansi (accounting) adalah suatu sistem informasi yang menyediakan laporan untuk para pemangku kepentingan mengenai aktivitas dan kondisi ekonomi perusahaan. Akuntansi menyediakan informasi bagi para pemangku kepentingan dalam perusahaan melalui proses diantaranya mengidentifikasi pemangku kepentingan, menilai kebutuhan pemangku kepentingan, merancang sistem informasi akuntansi untuk memenuhi kebutuhan pemangku kepentingan, mencatat data ekonomi mengenai aktivitas dan peristiwa perusahaan dan menyiapkan laporan akuntansi bagi para pemangku kepentingan.

Fungsi akuntansi adalah menganalisa dan mencatat transaksi-transaksi keuangan perusahaan, meringkas catatan-catatan mengenai transaksi-transaksi keuangan perusahaan menjadi laporan keuangan dan mengadakan interpretasi atas hasil-hasil transaksi keuangan perusahaan melalui analisis laporan keuangan. Berdasarkan aspek teknis, akuntansi didefinisikan sebagai proses pencatatan, pengukuran, dan penyampaian-penyampaian informasi ekonomi agar dapat dipakai sebagai dasar pengambilan keputusan atau kebijakan. Profesi akuntansi dalam praktiknya dibedakan menjadi dua yaitu akuntansi keuangan dan akuntansi manajerial. Akuntansi keuangan terkait dengan pencatatan dan pelaporan data dan aktvitas ekonomi suatu perusahaan. Akuntansi manajerial atau akuntansi manajemen menggunakan akuntansi keuangan maupun data estimasi untuk membantu manajemen dalam menjalankan aktivitas operasional harian dan merencanakan aktivitas operasional di masa depan.

Program Studi Akuntansi adalah salah satu jurusan di bidang ekonomi yang banyak diminati oleh mahasiswa karena akuntansi dapat menghasilkan lulusan yang 
kompeten dalam menyusun laporan keuangan. Lulusan akuntansi yang berkompeten sangat dibutuhkan oleh dunia usaha mengingat setiap perusahaan atau pemangku kepentingan membutuhkan laporan keuangan. Akuntansi memiliki peranan vital dan krusial dalam tatanan ekonomi suatu perusahaan, karena dalam setiap pengambilan keputusan (decision making) yang bersifat keuangan, harus berdasarkan pada informasi-informasi akuntansi.

Kenaikan dalam jumlah, ukuran, dan kompleksitas perusahaan telah meningkatkan kebutuhan masyarakat akan jasa di bidang akuntansi yang mendorong dan menjadikan akuntan sebagai suatu profesi yang sangat dibutuhkan. Program studi akuntansi memberikan mahasiswa pengetahuan mengenai penyusunan dan pemeriksaan laporan keuangan, teori dan perhitungan tentang perpajakan, auditing, akuntansi biaya, akuntansi manajemen, sistem informasi akuntansi, akuntansi untuk organisasi non laba, akuntansi sosial, dan analisis laporan keuangan.

Pendidikan akuntansi di Indonesia bertujuan menghasilkan lulusan yang beretika dan bermoral tinggi. Berbagai upaya dilakukan untuk memperkenalkan nilainilai profesi sebagai seorang akuntan yang profesional kepada mahasiswa. Upaya pengembangan pendidikan akuntansi yang berlandaskan profesionalisme dibutuhkan adanya umpan balik (feedback) mengenai kondisi yang ada sekarang, yaitu apakah pendidikan akuntansi di Indonesia telah cukup membentuk nilai-nilai positif mahasiswa akuntansi. Mahasiswa pada semester awal diwajibkan untuk menempuh mata kuliah akuntansi pengantar sebagai mata kuliah yang memegang peranan penting dan menentukan dalam mengantarkan para mahasiswa yang akan mempelajari akuntansi dan mata kuliah lain yang berkaitan pada tahapan berikutnya. Sebagai mata kuliah pengantar, mata kuliah ini dimaksudkan untuk memberikan pengetahuan dasar kepada para mahasiswa, sehingga pengetahuan dasar akuntansi yang dimiliki mahasiswa akan dipengaruhi oleh keberhasilan pembelajaran matakuliah ini.

Mahasiswa diharapkan dengan menempuh mata kuliah akuntansi pengantar, mahasiswa dapat memahami konsep dasar akuntansi secara baik. Menurut Weygant et al. (2012) ada tiga materi pokok tentang konsep dasar akuntansi yang harus 
dikuasai oleh mahasiswa akuntansi dalam kuliah Akuntansi Pengantar, yaitu pemahaman tentang aset, liabilitas, dan ekuitas. Mahasiswa akuntansi memandang mata kuliah Akuntansi Pengantar sebagai mata kuliah pokok yang akan memberi landasan penting dan memberi pengaruh yang besar pada keberhasilan mereka dalam menempuh mata kuliah akuntansi lain yang akan ditempuh pada tahun-tahun berikutnya.

Mata kuliah Akuntansi Pengantar merupakan mata kuliah bersyarat agar bisa melanjutkan ke mata kuliah akuntansi berikutnya, sehingga jika mahasiswa tidak mengikuti mata kuliah pengantar akuntansi ataupun dasar-dasar akuntansi tersebut maka mahasiswa tidak akan bisa melanjutkan ke mata kuliah selanjutnya. Menurut hasil penelitian Sar'i, Irsadsyah, dan Djamil (2010) adalah bertujuan untuk mengukur perbedaan pemahaman dan seberapa besar pemahaman mahasiswa yang berasal dari SMK Jurusan Akuntansi, SMA Jurusan IPS, dan Madrasah Aliyah Umum terhadap konsep dasar akuntansi.

Menurut Widowati, Surjawati, dan Nafasati (2011) menyatakan penelitian yang dilakukan bertujuan untuk memberikan bukti empiris mengenai tingkat pemahaman mahasiswa S1 Ekonomi Universitas Semarang terhadap konsep dasar akuntansi berdasar latar belakang pendidikan menengah yang dimiliki mahasiswa, yaitu mahasiswa dari latar belakang SMA jurusan IPA, SMA Jurusan IPS, SMEA, SMK, dan Madrasah Aliyah. Konsep akuntansi dalam penelitian ini adalah: aktiva, kewajiban, dan modal. Penelitian yang dilakukan oleh Mawardi (2011) tentang tingkat pemahaman mahasiswa akuntansi terhadap konsep dasar akuntansi di perguruan tinggi negeri di kota Malang menghasilkan bahwa dari ketiga variabel yang dijadikan pengukuran perbedaan tingkat pemahaman mahasiswa terhadap konsep dasar akuntansi yaitu aktiva, kewajiban dan modal dinyatakan tidak terdapat perbedaan pemahaman mahasiswa terhadap konsep dasar akuntansi.

Menurut Kusuma dan Bangun (2011) tentang analisis pemahaman mahasiswa akuntansi terhadap konsep aset, kewajiban dan ekuitas menghasilkan kesimpulan bahwa tidak terdapat perbedaan terhadap pemahaman aset, kewajiban, dan ekuitas antara mahasiswa yang berasal dari SMK jurusan akuntansi, SMU IPS dan SMU IPA 
yang menunjukkan bahwa latar belakang pendidikan menengah atas tidak memicu perbedaan pemahaman atas ketiga konsep tersebut. Perbedaan latar belakang pendidikan menengah atas tentunya akan mengakibatkan perbedaan kebiasan, pola pikir, dan daya tangkap masing-masing mahasiswa terhadap materi pembelajaran yang diberikan di perguruan tinggi khususnya pemahaman terhadap makna aset, kewajiban dan ekuitas, sehingga akan mempengaruhi tingkat pemhaman terhadap konsep dasar akuntansi.

Pemahaman mahasiswa akuntansi terhadap makna aset, kewajiban dan ekuitas yang tidak sepenuhnya dikuasai akan berpengaruh terhadap laporan keuangan yang akan dibuat. Laporan keuangan memiliki lima bentuk laporan yaitu laporan posisi keuangan (neraca), laporan laba rugi, laporan perubahan modal, laporan arus kas dan catatan atas laporan keuangan. Laporan posisi keuangan (neraca) memuat unsurunsur konsep dasar akuntansi yaitu sisi kanan memuat aset, dan sisi kiri memuat kewajiban dan ekuitas. Mahasiswa akuntansi jika tidak memiliki pemahaman yang matang terhadap konsep dasar akuntansi maka akan menyulitkan dalam membuat laporan neraca karena setiap laporan dalam laporan keuangan berkesinambungan, jadi ketika membuat laporan keuangan harus menguasai materi tentang konsep dasar akuntansi.

Penelitian ini mengembangkan penelitian dari Kusuma dan Bangun (2011) dengan lebih menganalisis faktor-faktor yang mempengaruhi pemahaman mahasiswa terhadap makna aset, kewajiban dan ekuitas, memperluas jangkauan responden dan memperbanyak jumlah responden dengan tujuan untuk mendapatkan data yang valid. Wilayah yang akan dijadikan tempat untuk penyebaran kuisioner adalah Kota Kediri. Alasan peneliti mereplikasi penelitian Budi Hartono Kusuma dan Nurainun Bangun adalah untuk mengetahui apakah terdapat perbedaan hasil penelitian yang pernah dilakukan dahulu dengan penelitian yang dilakukan saat ini. Penelitian ini menggunakan sampel yang berbeda dari penelitian sebelumnya dan variabel yang digunakan dalam penelitian ini berbeda dengan penelitian sebelumnya. Hipotesis penelitian adalah sebagai berikut: 
H1 : Perguruan tinggi berpengaruh terhadap pemahaman mahasiswa akuntansi tentang makna aset, kewajiban dan ekuitas.

H2 :Metode pembelajaran berpengaruh terhadap pemahaman mahasiswa tentang makna aset, kewajiban dan ekuitas.

H3 :Minat berpengaruh terhadap pemahaman mahasiswa akuntansi terhadap makna aset, kewajiban dan ekuitas.

H4 : Ada perbedaan pemahaman aset, kewajiban, dan ekuitas antara mahasiswa yang berasal dari SMK jurusan lain-lain, SMU IPS, dan SMU IPA

H5 :Perguruan tinggi, metode pembelajaran dosen akuntansi, minat dan jurusan asal sekolah berpengaruh terhadap pemahaman mahasiswa akuntansi terhadap makna aset, kewajiban dan ekuitas.

\section{METODE}

Penelitian ini termasuk jenis penelitian deskriptif kuantitatif. Penelitian deskriptif kuantitatif merupakan penelitian yang menekankan pada pengujian teoriteori melalui pengukuran variabel-variabel penelitian dengan angka dan melakukan analisis data dengan prosedur statistik (Indriantoro dan Supomo, 2009:12). Data yang digunakan dalam penelitian ini adalah data primer. Teknik pengumpulan data dalam penelitian ini menggunakan kuisioner. Penyebaran kuesioner dilakukan dengan dengan cara pemberian langsung oleh peneliti ke semua responden yang menjadi populasi penelitian.

Populasi dalam penelitian ini adalah mahasiswa jurusan akuntansi pada perguruan tinggi swasta di kota Kediri antara lain Politeknik Kediri, Universitas Nusantara PGRI Kediri, Universitas Islam Kadiri, dan Universitas Pawyatan Daha. Metode penyampelan yang digunakan dalam penelitian ini adalah Purposive Sampling. Purposive Sampling yaitu teknik pengambilan sampel disesuaikan dengan kriteria atau pertimbangan tertentu, sebagai berikut: (1) Mahasiswa akuntansi adalah mahasiswa yang telah lulus mata kuliah akuntansi pengantar 1 dan 2 karena dalam mata kuliah tersebut telah mencakup pengertian dan makna aset, kewajiban dan ekuitas dalam arti yang sebenarnya; (2) Mahasiswa akuntansi yang sedang atau telah 
menempuh minimal pada semester 2. Hasil perhitungan sampel yang digunakan dalam penelitian ini sebagai berikut:

Tabel 1. Hasil Perhitungan Sampel Penelitian

\begin{tabular}{llcc}
\hline No & \multicolumn{1}{c}{ Responden } & $\begin{array}{c}\text { Jumlah Kuisoner } \\
\text { yang dibagikan }\end{array}$ & $\begin{array}{c}\text { Jumlah kuisoner } \\
\text { yang kembali dan } \\
\text { dapat digunakan }\end{array}$ \\
\hline \multicolumn{2}{l}{$\begin{array}{l}\text { Mahasiswa Pendidikan Vokasi } \\
\text { 1. }\end{array}$} & 53 & 51 \\
& $\begin{array}{l}\text { Politeknik Kediri } \\
\text { Mahasiswa Pendidikan } \\
\text { Akademik }\end{array}$ & 20 & 18 \\
1. $\quad$ Universitas Islam Kadiri & 20 & 19 \\
2. $\quad \begin{array}{l}\text { Universitas Nusantara PGRI } \\
\text { Kediri }\end{array}$ & 15 & 13 \\
3. Universitas Pawyatan Daha & \multicolumn{1}{c}{ Total Responden } & 108 & 101 \\
\hline
\end{tabular}

Sumber : Data Diolah 2015

\section{Uji Reliabilitas}

Konsep Reliabilitas dapat dipahami melalui ide dasar konsep tersebut yaitu konsistensi. Pengukuran reliabilitas menggunakan indeks numeric yang disebut dengan koefisien (Indiantoro, Supomo 2009). Suatu instrumen penelitian dikatakan reliabel dengan menggunakan teknik alpa cronbach, bila koefisien reliabilitas > 0,6. Tabel 2 menampilkan hasil uji reliabiltas.

\section{Tabel 2 Hasil Uji Reliabilitas}

\begin{tabular}{|c|c|}
\hline Variabel & 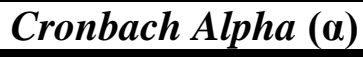 \\
\hline Perguruan Tinggi (PT) & 0,740 \\
\hline Metode Pembelajaran (MP) & 0,648 \\
\hline $\begin{array}{l}\text { Minat Terhadap Mata Kuliah Akuntansi } \\
\text { (MK) }\end{array}$ & 0,636 \\
\hline Jurusan Asal Sekolah (JUR) & 0,721 \\
\hline Makna Aset, Kewajiban, dan Ekuitas (AKE) & 0,895 \\
\hline
\end{tabular}

Sumber: Data Diolah

Hasil yang diperoleh memenuhi konsep realibilitas dengan nilai Cronbach Alpha $(\alpha)$ diatas 0,60 , sehingga dikatakan semua variabel reliabel. 


\section{Uji Validitas}

Validitas data penelitian ditentukan oleh proses pengukuran yang akurat. Suatu instrumen pengukur dikatakan valid jika instrument tersebut mengukur apa yang seharusnya diukur. Tabel 4.2 menunjukkan hasil uji validitas.

Tabel 3. Hasil Uji Validitas

\begin{tabular}{llll}
\hline \multicolumn{1}{c}{ Variabel } & $\begin{array}{l}\text { Kaiser Mayer } \\
\text { Olkin (KMO) }\end{array}$ & $\begin{array}{c}\text { Bartlett's Test } \\
\text { Chi-Square }\end{array}$ & Sig. \\
\hline Perguruan Tinggi (PT) & 0,697 & 110,499 & 0,000 \\
Metode Pembelajaran (MP) & 0,649 & 117,149 & 0,000 \\
Minat Terhadap Mata Kuliah & 0,646 & 75,562 & 0,000 \\
Akuntansi (MK) & & & \\
Jurusan Asal Sekolah (JUR) & 0,695 & 77,258 & 0,000 \\
Makna Aset, Kewajiban dan & 0,686 & 1300,606 & 0,000 \\
Ekuitas (AKE) & & & \\
\hline
\end{tabular}

Sumber: Data Diolah

Berdasarkan hasil dari uji validitas dengan menggunakan uji Confirmatory Factor Analysis (CFA) menghasilkan nilai untuk konstruk perguruan tinggi dengan nilai Kaiser Mayer Olkin (KMO) 0,697 sehingga dapat dilakukan analisis faktor, nilai Bartlett's Test Chi-Square 110,499 dan signifikan pada 0,000, sehingga dapat disimpulkan bahwa uji analisis faktor dengan konstruk perguruan tinggi dapat dilanjutkan dan bisa dikatakan valid. Konstruk selanjutnya adalah metode pembelajaran dengan nilai Kaiser Mayer Olkin (KMO) 0,649 sehingga dapat dilakukan analisis faktor, sedangkan nilai Bartlett's Test Chi-Square menunjukkan hasil sebesar 117,149 dan signifikan pada 0,000, sehingga disimpulkan bahwa uji analisis faktor dengan konstruk metode pembelajaran dapat dilanjutkan dan bisa dikatakan valid.

Minat Terhadap Mata Kuliah Akuntansi adalah konstruk ketiga dengan nilai Kaiser Mayer Olkin (KMO) 0,646 sehingga dapat dilakukan analisis faktor, sedangkan nilai Bartlett's Test Chi-Square menunjukkan hasil sebesar 75,562 dan 
signifikan pada 0,000, sehingga disimpulkan bahwa uji analisis faktor dengan konstruk Minat Terhadap Mata Kuliah Akuntansi dapat dilanjutkan dan bisa dikatakan valid. Konstruk keempat adalah jurusan asal sekolah dengan nilia Kaiser Mayer Olkin (KMO) 0,695 sehingga dapat dilakukan analisis faktor, sedangkan nilai Bartlett's Test Chi-Square menunjukkan hasil sebesar 77,258 dan signifikan pada 0,000, sehingga disimpulkan bahwa uji analisis faktor dengan konstruk jurusan asal sekolah dapat dilanjutkan dan bisa dikatakan valid. Konstruk terakhir adalah makna aset, kewajiban dan ekuitas dengan nilai Kaiser Mayer Olkin (KMO) 0,686 sehingga dapat dilakukan analisis faktor, sedangkan nilai Bartlett's Test Chi-Square menunjukkan hasil sebesar 1300,606 dan signifikan pada 0,000, sehingga disimpulkan bahwa uji analisis faktor dengan konstruk metode makna aset, kewajiban dan ekuitas dapat dilanjutkan dan bisa dikatakan valid.

\section{HASIL DAN PEMBAHASAN}

\section{HASIL}

Berdasarkan hasil uji koefisien determinasi $\left(\mathrm{R}^{2}\right)$ menunjukkan nilai untuk adjusted $R$ Square adalah 0,754, hal ini menunjukkan 75,4\% variasi makna aset, kewajiban dan ekuitas dapat dijelaskan oleh variasi ke empat variabel independen perguruan tinggi, metode pembelajaran, Minat Terhadap Mata Kuliah Akuntansi dan jurusan asal sekolah, sedangkan sisanya $(100 \%-75,4 \%=24,6 \%)$ dijelaskan oleh sebab-sebab lain di luar model. Tabel 4 menunjukkan hasil uji koefisien determinasi.

Tabel 4. Hasil Uji Koefisien Determinasi $\left(\mathbf{R}^{2}\right)$

\begin{tabular}{cccc}
\hline Model 1 & $\mathbf{R}$ & $\mathbf{R}^{\mathbf{2}}$ & Adjusted R Square \\
\hline 1 & $0,874^{\mathrm{a}}$ & 0,764 & 0,754 \\
\hline
\end{tabular}

Uji Keberartian Model (Uji F)

Tabel 5. Hasil Uji Keberartian Model (Uji F)

\begin{tabular}{ccc}
\hline Model & F & Sig. \\
\hline Regression Residual & 77,778 & 0,000 \\
\hline
\end{tabular}

Sumber: Data Diolah

Uji ANOVA atau $F$ test didapat nilai $F$ hitung sebesar 77,778 dengan probabilitas 0,000 , karena probabilitas jauh lebih kecil dari 0,005, maka model regresi 
dapat digunakan untuk memprediksi makna aset, kewajiban dan ekuitas atau dapat dikatakan bahwa perguruan tinggi, metode pembelajaran, Minat Terhadap Mata Kuliah Akuntansi, dan jurusan asal sekolah secara bersama-sama berpengaruh terhadap makna aset, kewajiban dan ekuitas.

\section{Uji Signifikansi Parameter Individual (Uji t)}

\section{Tabel 6. Hasil Uji Signifikansi Parameter Individual (Uji t)}

\begin{tabular}{ccccc}
\hline \multicolumn{5}{c}{ Unstadardized Coefficient } \\
\hline Model & B & Std.Erorr & P & Sig. \\
\hline 1. (constant) & 0,231 & 0,271 & 0,851 & 0,397 \\
PT & -0.39 & 0,048 & $-0,811$ & 0,419 \\
MP & 0,068 & 0,052 & 1,310 & 0,193 \\
MK & 0,0750 & 0,073 & 10,243 & $0,000^{*}$ \\
JUR & 0,169 & 0,052 & 3,270 & $0,001^{*}$ \\
\hline
\end{tabular}

$*=$ signifikan di level $\alpha=5 \%$

Berdasarkan pengolahan data, hasil penelitian diatas persamaan diatas menunjukkan bahwa variabel perguruan tinggi berpengaruh tetapi tidak signifikan terhadap makna aset, kewajiban dan ekuitas. Hasil ini ditunjukkan dengan nilai $\mathrm{P}$ sebesar -0,811 dengan sig sebesar 0,419. Variabel metode pembelajaran berpengaruh tetapi tidak signifikan terhadap makna aset, kewajiban dan ekuitas. Hasil ini ditunjukkan dengan nilai P sebesar 1,310 dan sig sebesar 0,193. Variabel minat mata kuliah akuntansi terhadap makna aset, kewajiban dan ekuitas dengan berpengaruh dan signifikan terhadap makna aset, kewajiban dan ekuitas. Hasil ini ditunjukkan dengan nilai P sebesar 10,243 dengan sig sebesar 0,000. Sedangkan berdasarkan pengolahan data, hasil penelitian diatas menunjukkan bahwa variabel jurusan asal sekolah berpengaruh positif dan signifikan terhadap makna aset, kewajiban dan ekuitas. Hasil ini ditunjukkan dengan nilai $\mathrm{P}$ sebesar 3,270 dengan sig 0,001. Lebih lanjut, Berdasarkan hasil uji keberartian model (uji F) dengan variabel perguruan tinggi, metode pembelajaran, minat mata kuliah akuntansi dan jurusan asal sekolah berpengaruh positif secara signifikan dengan nilai $F$ 77,778 dan sig 0,000. Hal ini menunjukkan bahwa variabel-variabel independen secara bersama-sama 
mempengaruhi pemahaman mahasiswa akuntansi terhadap makna aset, kewajiban dan ekuitas.

\section{PEMBAHASAN}

\section{Perguruan Tinggi Terhadap Makna Aset, Kewajiban dan Ekuitas}

Berdasarkan pengolahan data, hasil penelitian diatas persamaan diatas menunjukkan bahwa variabel perguruan tinggi berpengaruh tetapi tidak signifikan terhadap makna aset, kewajiban dan ekuitas. Hasil ini ditunjukkan dengan nilai $\mathrm{P}$ sebesar -0,811 dengan sig sebesar 0,419. Hasil penelitian ini sesuai dengan penelitian yang dilakukan oleh Marita dan Diyan Mayasari (2006) yang menyatakan bahwa perguruan tinggi tidak mempengaruhi pemahaman mahasiswa akuntansi terhadap makna cost. Penulis beranggapan bahwa perguruan tinggi tidak mempengaruhi makna aset, kewajiban dan ekuitas. Pada dasarnya setiap perguruan tinggi baik perguruan tinggi vokasi maupun akademik sama-sama menekankan penguasaan materi, tetapi perguruan tinggi akademik lebih menekankan kepada penguasaan materi, sedangkan perguruan tinggi vokasi menekankan praktik dari pada penguasaan materi.

\section{Metode Pembelajaran Terhadap Makna Aset, Kewajiban dan Ekuitas}

Berdasarkan pengolahan data, hasil penelitian diatas menunjukkan bahwa variabel metode pembelajaran berpengaruh tetapi tidak signifikan terhadap makna aset, kewajiban dan ekuitas. Hasil ini ditunjukkan dengan nilai $\mathrm{P}$ sebesar 1,310 dan sig sebesar 0,193. Hasil penelitian ini sesuai dengan hipotesis yang disusun oleh penulis yang menyatakan bahwa metode pembelajaran tidak pemahaman mahasiswa akuntansi terhadap makna aset, kewajiban dan ekuitas. Setiap metode pembelajaran baik metode diskusi, metode berpusat kepada mahasiswa dan metode ceramah memiliki cara penyampaian yang berbeda tetapi penguasaan materi atau pendalaman materi tergantung dari setiap mahasiswa. Penulis menyimpulkan bahwa metode pembelajaran tidak mempengaruhi makna aset, kewajiban dan ekuitas. 


\section{Minat Mata Kuliah Akuntansi Terhadap Makna Aset, Kewajiban dan Ekuitas}

Berdasarkan pengolahan data, hasil penelitian diatas menunjukkan bahwa variabel minat mata kuliah akuntansi terhadap makna aset, kewajiban dan ekuitas dengan berpengaruh dan signifikan terhadap makna aset, kewajiban dan ekuitas. Hasil ini ditunjukkan dengan nilai P sebesar 10,243 dengan sig sebesar 0,000. Hasil penelitian ini tidak sejalan dengan penelitian yang dilakukan oleh Marita dan Diyan Mayasari (2006) yang menyatakan bahwa minat mata kuliah akuntansi mempengaruhi pemahaman mahasiswa akuntansi terhadap makna cost. Penulis beranggapan bahwa minat mata kuliah akuntansi yang terdiri dari akuntansi keuangan, akuntansi manajemen, akuntansi sektor publik, dll mempengaruhi makna aset, kewajiban dan aset. Minat mata kuliah akuntansi setiap mahasiswa berbeda-beda sehingga tingkat pemahaman mahasiswa juga turut dipengaruhi oleh minat mata kuliah akuntansi.

\section{Jurusan Asal Sekolah Terhadap Makna Aset, Kewajiban dan Ekuitas}

Berdasarkan pengolahan data, hasil penelitian diatas menunjukkan bahwa variabel jurusan asal sekolah berpengaruh positif dan signifikan terhadap makna aset, kewajiban dan ekuitas. Hasil ini ditunjukkan dengan nilai P sebesar 3,270 dengan sig 0,001. Hasil penelitian ini tidak sejalan dengan penelitian yang dilakukan oleh Marita dan Diyan Mayasari (2006) yang menyatakan bahwa jurusan asal sekolah mempengaruhi pemahaman mahasiswa akuntansi terhadap makna cost. Pemahaman dasar mengenai aset, kewajiban dan ekuitas antara mahasiswa akuntansi yang berasal dari jurusan SMA IPS, SMA IPA, dan SMK jurusan lain-lain bisa dikuasai mahasiswa akuntansi.

\section{Perguruan Tinggi, Metode Pembelajaran, Minat Mata Kuliah Akuntansi, Jurusan Asal Sekolah Terhadap Makna Aset, Kewajiban Dan Ekuitas}

Berdasarkan hasil uji keberartian model (uji F) dengan variabel perguruan tinggi, metode pembelajaran, minat mata kuliah akuntansi dan jurusan asal sekolah berpengaruh positif secara signifikan dengan nilai $F 77,778$ dan sig 0,000 . Hal ini 
menunjukkan bahwa variabel-variabel independen secara bersama-sama mempengaruhi pemahaman mahasiswa akuntansi terhadap makna aset, kewajiban dan ekuitas. Hasil ini tidak sejalan dengan hipotesis yang disusun oleh penulis yang menyatakan bahwa perguruan tinggi, metode pembelajaran, minat mata kuliah dan jurusan asal sekolah tidak mempengaruhi pemahaman mahasiswa akuntansi terhadap makna aset, kewajiban dan ekuitas.

\section{SIMPULAN}

Hasil penelitian di atas merupakan jenis penelitian desktiptif kuantitatif. Penelitian ini menggunakan empat variabel independen yaitu perguruan tinggi, metode pembelajaran, minat mata kuliah akuntansi dan jurusan asal sekolah, sedangkan variabel dependen adalah makna aset, kewajiban dan ekuitas. Penelitian ini menguji variabel-variabel independen berpengaruh secara signifikan terhadap variabel dependen. Sampel yang digunakan dalam penelitian ini adalah mahasiswa yang telah mengambil mata kuliah akuntansi pengantar 1 dan 2 atau minimal berada pada semester 2. Jumlah data dalam penelitian ini adalah 101 responden.

Variabel perguruan tinggi secara parsial tidak berpengaruh terhadap minat aset, kewajiban dan ekuitas dan metode pembelajaran secara parsial juga tidak berpengaruh terhadap minat aset, kewajiban dan ekuitas. Minat mata kuliah akuntansi secara parsial berpengaruh signifikan terhadap makna aset, kewajiban dan ekuitas dan jurusan asal sekolah secara parsial berpengaruh signifikan terhadap makna aset, kewajiban dan ekuitas.

\section{DAFTAR PUSTAKA}

Ghozali, Imam. 2006. Statistik Non-parametrik. Teori dan Aplikasi dengan Program SPSS. Universitas Diponegoro. Semarang. 
Indriantoro, Nur dan Bambang Supomo. 2009. Metodologi Penelitian Bisnis untuk Akuntansi dan Manajemen. Edisi Pertama. BPFE UGM Yogyakarta.

Kusuma dan Nurainun Bangun. 2011. Analisis Pemahaman Mahasiswa Akuntansi Terhadap Konsep Aset, Kewajiban dan Ekuitas. Jurnal Bisnis dan Akuntansi. Vol 13. No 3. Hal 183-194.

Mawardi, M.Cholid. 2011. Tingkat Pemahaman Akuntansi Terhadap Konsep Dasar Akuntansi. Artikel Akuntansi Fakultas Ekonomi Universitas Islam, Malang.

Mayasari, Diyan dan Marita. 2006. Analisis Faktor-Faktor yang Mempengaruhi Pemahaman Mahasiswa Akuntansi Terhadap Makna Cost. Jurnal Solusi. Vol 1. No. 1 Hal. 43-61.

Sar'i, Muhammad, Muhammad Irsadsyah, dan Nasrullah Djamil. 2010. Analisis Tingkat Pemahaman Mahasiswa Akuntansi Terhadap Konsep Dasar Akuntansi. Simposium Nasional Akuntansi XIII. Purwokerto.

Weygandt, Jerry J., Donald E. Kieso, dan Paul D. Kimmel. 2012. Financial Accounting.IFRS Edition. John Wiley and Sons, Inc.

Widowati, Sujarwati dan Febrina Nafasati. 2011. Analisis Tingkat Pemahaman Mahasiswa S1 Akuntansi dan Manajemen Terhadap Konsep Dasar Akuntansi (Studi Empiris Pada Mahasiswa S1 Akuntansi Dan Manajemen Universitas Semarang). Jurnal Dinamika Sosbud. Vol 13. No 1. Hal 1-18. 